\author{
І.В. Жиглей, д.е.н., проф. \\ Д.С. Осіпчук, магістрант \\ Державний університет «Житомирська політехніка»
}

\title{
Експорт товарів і послуг: спільні та відмінні риси обліку й оподаткування
}

\begin{abstract}
Розглянуто складові експортних операцій, зокрема, експорт товарів та послуг. Досліджено їх динаміку за 2013-2018 рр., встановлено основні тендениії обсягів постачання товарів та послуг нерезидентам. Проаналізовано основні нововведення у сфері законодавства щодо здійснення зовнішньоекономічних операцій. Розглянуто первинні документи, на підставі яких здійснюється відображення господарських операчій з експорту в системі бухгалтерського обліку. Визначено особливості визнання доходу при реалізачії товарів та послуг нерезидентам. Розглянуто, на яких рахунках відбувається відображення операцій з експорту. Встановлено особливості оподаткування податком на додану вартість експорту товарів та послуг. Виявлено спільні та відмінні риси обліку й оподаткування таких операцій. Розроблено алгоритм визначення ставки ПДВ при постачанні послуг нерезиденту. Здійснено узагальнення особливостей експорту товарів та послуг та їх впливу на бухгалтерський облік ци оподаткування. Проведено систематизачію нормативних вимог щодо методики відображення експортних операцій в бухгалтерського обліку з метою зменшення кількості облікових помилок.

Ключові слова: експорт товарів; експорт послуг; зовнішньоекономічна діяльність; оподаткування експорту.
\end{abstract}

Актуальність теми. Експорт $є$ важливою складовою зовнішньоекономічної діяльності будь-якої держави. Завдяки експортним операціям здійснюється рух товарів, послуг, робочої сили, капіталів, а також валютних цінностей, що допомагають поповнити валютні резерви країни. Для підприємствекспортерів це додатковий стимул для покращення якості продукції, збільшення обсягів виробництва, освоєння додаткових ринків збуту, що в кінцевому підсумку призведе до збільшення прибутків. Тому експорт позитивно впливає як на суб’єктів господарювання, так і на державу. У 2019 р. в Україні було прийнято нове законодавство у сфері регулювання валютних операцій, що дозволило певним чином лібералізувати зовнішньоекономічні відносини. Так за 2017-2018 рр. обсяг експорту товарів знизився на 9,1\% [25]. Тому ряд знятих обмежень покликаний стимулювати експорт, який протягом останніх років має тенденцію до зниження. Починаючи з 2013 р., відбувалося стрімке падіння обсягу експортних операцій, лише 2016-2017 рр. показали позитивний приріст: 2013-2014 pp. -14,88 \%, 2014-2015 рр. -29,27\%, 2015-2016 pp. -4,63\%, 2016-2017 pp. +18,9\%, 2017-2018 pp. -9,1\% [25].

В українській практиці поширеним явищем $є$ як експорт товарів, так і експорт послуг. Проте чинне законодавство визначає різний порядок оподаткування, документування, нагляду та контролю за такими операціями, що вимагає дослідження спільних та відмінних рис обліку та оподаткування операцій 3 експорту товарів та послуг.

Аналіз останніх досліджень. У статті досліджено переважно проблеми практичного облікового відображення та оподаткування операцій з експорту та імпорту, у зв'язку з чим основною базою дослідження була періодична література 3 обліку та оподаткування, в якій авторами статей були Ю.Волотковська [4], К.Давидова [7], О.Сфімчук [8, 9], О.Кантермана [12], О.Коваленко [14], Т.Михайлової [17], О.Рижикової [24], М.Форостиної [27], О.Целуйко [28], А.Юліна [30] та ін., а також оновлена в 2019 р. нормативна база.

Серед наукових досліджень в останні роки ця тематика не є особливо популярною. Аналіз публікацій вітчизняних вчених дозволив виокремити праці В.Ю. Гордополова [5, 6] , І.Жиглей [10, 11], Н.Г. Карпенко [13], В.К. Ксендзук [15], Н.В. Оляднічук [19], С.В. Сисюк [26]. У той самий час праці, які б відображали останні законодавчі новації, їх вплив на облік та оподаткування операцій з експорту товарів та послуг, в науковій літературі відсутні.

Метою статті є визначення спільних та відмінних рис обліку та оподаткування операцій з експорту товарів та послуг, що дозволить сформувати відповідний методичний підхід, який дозволить зменшити кількість помилок та порушень, зробить інформацію більш прозорою.

Викладення основного матеріалу. Експорт - вивіз товару, робіт, послуг, результатів інтелектуальної діяльності, зокрема виняткових прав на них, з митної території країни за кордон без зобов'язання про зворотне ввезення [18]. Розрізняють декілька видів експорту, а саме: товарів, робіт, послуг, капіталів, робочої сили. У цій статті ми розглянемо два основні та найбільш поширені в Україні: експорт товарів та послуг. Ці два види експорту мають як спільні, так і відмінні риси. Вони 
проявляються і у сфері митного оформлення, і у сфері оподаткування, і у сфері облікового відображення. Тому важливо розглянути їх більш детально.

Бухгалтерський облік за своєю природою є досить регламентований на законодавчому рівні, тобто відображення будь-якої операції здійснюється на основі відповідних нормативних положень. Можна вирізнити нормативні документи, що діють прямо на облік (ті, що безпосередньо вказують як, що і коли відображати), та ті, що діють опосередковано (непрямо регулюють облікові аспекти, такі як порядок документування, визначення дати, за якою відображати операцію, визначення самого об'єкта обліку тощо).

Нормативними документами, що прямо впливають на бухгалтерський облік експортних операцій, $є$ П(С)БО 21 «Вплив змін валютних курсів» [3], МСБО 21 «Вплив змін валютних курсів» [2] та Податковий кодекс України [20]. Опосередковано на облік експорту впливають: Митний кодекс України [16], 3У «Про зовнішньоекономічну діяльність» [23], 3У «Про валюту і валютні операції» [22].

Бухгалтерський облік експорту товарів та послуг має як спільні, так і відмінні риси. Перш за все це зумовлено тим, що послуги не перетинають кордон і не потребують митного оформлення, тому тут виникають інші особливості, а саме в сфері оподаткування. Першу відмінність можна побачити вже у визначенні понять «експорту товарів» та «експорту послуг». Зокрема у ЗУ «Про зовнішньоекономічну діяльність» наводиться таке визначення: «експорт - продаж товарів українськими суб'єктами зовнішньоекономічної діяльності іноземним суб'єктам господарської діяльності (у тому числі з оплатою в негрошовій формі) 3 вивезенням або без вивезення цих товарів через митний кордон України, включаючи реекспорт товарів» [23]. Проте визначення експорту послуг є відсутнім як у цьому законі, так i в інших нормативних документах. Можна сказати, що експорт послуг полягає у наданні послуг підприємством-резидентом, підприємству (установі) -нерезиденту.

Як завжди, усі господарські операції в системі бухгалтерського обліку відображаються на підставі первинних документів. Відповідно підставою для відображення в системі бухгалтерського обліку експорту товарів $є$ : рахунок-фактура (інвойс), CMR або морська накладна, або авіа накладна, або залізнична накладна (залежно від виду транспорту), а для експорту послуг - Акт надання послуг або інший погоджений сторонами документ. Оскільки експорт за своєю суттю є операцією 3 реалізації, то для цілей оподаткування постає питання дати визнання доходу, тобто дати, за якою бухгалтер має відобразити здійснену операцію. П(С)БО 15 «Дохід» визначає, що дохід визнається якщо:

- покупцю передано всі ризики та вигоди, пов'язані з правом власності на продукцію;

- продавець не здійснює управління та контроль за реалізованою продукцією;

сума доходу може бути достовірно визначена;

- $\quad \epsilon$ впевненість, що в результаті операції станеться збільшення економічних вигод підприємства, а витрати, пов'язані з цією операцією, можуть бути достовірно визначені [1].

При експорті товарів не завжди дата оформлення митної декларації чи дата інвойсу відповідають тій даті, на яку виконуються прописані в П(С)БО 15 щодо визнання доходу, оскільки це залежить від умов постачання. Тому дохід за експортною операцією слід відображати на дату останньої з подій: передання ризиків і втрати контролю. Якщо втрата контролю продавця здійснюється в момент передачі продукції перевізнику покупця, то момент передачі ризиків, пов'язаних із правом власності на продукцію, залежить від базисних умов поставки ІНКОТЕРМС. Що стосується послуг, то тут дещо простішим $є$ визначення дати визнання доходу. Це пов'язано з тим, що послуги не перетинають кордон і не підлягають митному оформленню, тому датою визнання доходу є дата оформлення Акта наданих послуг. Проте, не завжди дохід визнається тільки на дату складання акта. Його визнають ще й на кожну дату балансу з урахуванням вимог пп. 10-14 П(С)БО 15:

а) виходячи зі ступеня завершеності операції - якщо одночасно виконуються всі такі умови: дохід може бути достовірно визначений;

- імовірне надходження економічних вигод;

- можлива достовірна оцінка ступеня завершеності надання послуг на дату балансу;

- можлива достовірна оцінка витрат, здійснених для надання послуг i необхідних для їх завершення;

б) виходячи з суми витрат, що підлягають відшкодуванню, - якщо така сума визначена [1].

Також необхідним є документальне підтвердження часткового визнання доходу. Для цього бухгалтером може бути виписана бухгалтерська довідка з усіма реквізитами, що підтверджуватиме факт визнання доходу.

Відображення експортних операцій у системі бухгалтерського обліку потребує також достовірної оцінки. Зазвичай складність оцінки експортних операцій полягає у тому, що ці операції виражені в іноземній валюті, яка потребує переведення у валюту звітності, а також виникнення курсових різниць, що дещо ускладнюють життя бухгалтеру. Для того щоб визначити, за яким курсом здійснюється відображення операції, у валюті звітності застосовується П(С)БО 21 «Вплив змін валютних курсів» або МСБО 21 «Вплив зміни валютних курсів» залежно від обраної облікової політики підприємства. Згідно 3 П(С)БО 21, операції в іноземній валюті відображаються: 
- під час первісного визнання відображаються у валюті звітності шляхом перерахунку суми в іноземній валюті із застосуванням валютного курсу на початок дня, дати здійснення операції (дати визнання активів, зобов'язань, власного капіталу, доходів і витрат);

- сума авансу (попередньої оплати) в іноземній валюті, надана іншим особам у рахунок платежів для придбання немонетарних активів (запасів, основних засобів, нематеріальних активів тощо) i отримання робіт і послуг, при включенні до вартості цих активів (робіт, послуг) перераховується у валюту звітності із застосуванням валютного курсу на початок дня дати сплати авансу. У разі здійснення авансових платежів в іноземній валюті постачальникові частинами та одержання частинами від постачальника немонетарних активів (робіт, послуг) вартість одержаних активів (робіт, послуг) визнається за сумою авансових платежів із застосуванням валютних курсів, виходячи 3 послідовності здійснення авансових платежів [3].

На даний момент часу НБУ встановлює курс щодня один раз наприкінці робочого дня, що діє протягом усього наступного дня. Тобто це означає, що курс на початок та кінець дня є однаковим. Тому можна сказати, що для перерахунку іноземної валюти у валюту звітності застосовується курс НБУ, який діє на дату першої події (відвантаження або дата отримання авансу) за експортною операцією у межах суми такої операції. Що ще раз свідчить про важливість визначення дати здійснення операції. Якщо продавцем було отримано аванс, то використовується дата зарахування коштів від покупця на розподільчий рахунок у банку.

Також поряд 3 відображенням операцій в іноземній валюті у валюті звітності виникають курсові різниці щодо монетарних статей. Згідно з П(С)БО 21, під монетарною статтею розуміють статті балансу про грошові кошти, а також про такі активи й зобов'язання, які будуть отримані або сплачені у фіксованій (або визначеній) сумі грошей або їх еквівалентів [3]. Тобто це ті статті, які в майбутньому будуть погашені грошовими коштами. Статті, погашення яких буде відбуватися негрошовими коштами, визнаються немонетарними та не підлягають переоцінці. Щодо питання переоцінки монетарних статей звертаємося також до П(С)БО 21, який визначає, на яку дату здійснюється визначення курсових різниць. Визначення курсових різниць за монетарними статтями в іноземній валюті проводиться на дату балансу, а також на дату здійснення господарської операції в іiі межах або за всією статтею (відповідно до облікової політики). Для визначення курсових різниць на дату балансу застосовується валютний курс на кінець дня дати балансу. При визначенні курсових різниць на дату здійснення господарської операції застосовується валютний курс на початок дня дати здійснення операції [3]. Важливо зазначити, що монетарною статтею є не лише дебіторська заборгованість за товари чи послуги, а і валютні кошти на розподільчому і поточному рахунках, тому при їх списанні і на дату балансу також рахуються курсові різниці.

Якщо говорити про відображення курсових різниць в бухгалтерському обліку, то це залежить відповідно від виду курсової різниці: операційна чи неопераційна, позитивна чи негативна. Позитивні курсові різниці відображаються у складі доходів, а негативні у складі витрат. При цьому їх поділ на операційні та неопераційні визначає, до складу яких доходів і витрат їх зараховувати. Якщо курсова різниця виникає від переоцінки монетарних статей операційної діяльності, то така різниця відображається у складі доходів або витрат від операційної діяльності, а якщо від фінансової чи інвестиційної діяльності, то відображається відповідно у складі інших доходів і витрат.

Для відображення експортних операцій використовують ті самі рахунки, що використовується при звичайній реалізації товарів або послуг, але оскільки експортні операції виражені в іноземній валюті, то $є$ ж певні відмінності:

- при наступній оплаті використовується субрахунок 362 «Розрахунки з іноземними покупцями» у кореспонденції з доходним рахунком 70 «Доходи від реалізації»;

при попередній оплаті застосовуються рахунки обліку грошових коштів, а саме: 316 «Спеціальні рахунки в іноземній валюті» в кореспонденції з 681 «Розрахунки за авансами одержаними». Відповідно після настання дати визнання доходу по операції, яка мала попередню оплату, використовуються ті самі рахунки, що і при наступній оплаті.

Експорт товарів та послуг згідно з Податковим кодексом України є об’єктом оподаткування ПДВ.

При вивезенні товарів у митному режимі експорту та реекспорту застосовується ставка ПДВ $0 \%$. Однак для того щоб застосовувати цю ставку, необхідно мати документальне підтвердження того, що така операція $є$ дійсно експортною. Таким документальним підтвердженням $є$ митна декларація, яка оформлена згідно з вимогами Митного кодексу України.

Датою виникнення податкових зобов'язань з ПДВ при експорті є дата оформлення митної декларації, що засвідчує факт перетинання митного кордону [20].

3 метою визначення, згідно з п. 187.1 ст. 187 Податкового кодексу, дати виникнення податкового зобов'язання з ПДВ у разі експорту товарів датою оформлення митної декларації вважається дата завершення процедури митного оформлення експортної операції, яка визначається за фактом проставлення посадовою особою митного органу на всіх аркушах такої декларації відбитка особистої 
номерної печатки, а в разі електронного декларування - за фактом засвідчення електронним цифровим підписом посадової особи митного органу електронної митної декларації після перетворення іiі у візуальну форму [12]. Тобто у разі коли дата оформлення митної декларації та дата фактичного перетину товаром митного кордону України припадають на різні податкові періоди, датою виникнення податкових зобов'язань за операціями з вивезення товарів за межі митної території України є дата оформлення митної декларації.

На дату виникнення податкових зобов'язань з ПДВ суб'єкт господарювання має виписати та зареєструвати податкову накладну. Складання податкової накладної при експорті має ряд особливостей. Обидва примірники цієї накладної залишаються у продавця. Ставиться помітка «Х» у клітинці, що означає, що така накладна не підлягає наданню утримувачу та зазначається тип причини. Для експортних операцій проставляється код 07 - «складена на операції з вивезення товарів за межі митної території України».

У разі здійснення операцій з вивезення товарів за межі митної території України у графі «Отримувач (покупець)» зазначаються найменування (ПІБ) нерезидента та через кому - країна, в якій зареєстрований покупець (нерезидент), а у рядку «Індивідуальний податковий номер отримувача (покупця)» проставляється умовний ІПН «300000000000», рядок «Податковий номер платника податку або серія (за наявності) та номер паспорта» не заповнюється [21].

Складається податкова накладна на операції з вивезення товарів за межі митної території України 3 урахуванням офіційного курсу гривні до іноземних валют та курсу банківських металів, який встановлено Нацбанком України у попередній робочий день.

При експортних операціях для визначення бази оподаткування ПДВ слід користуватися приписами п. 188.1 Податкового кодексу України, а отже, базою оподаткування операцій 3 постачання товарів/послуг буде їх договірна (контрактна) вартість, але не нижча за звичайні ціни [20].

При визначенні бази оподаткування за експортною операцією слід враховувати, що вона не може бути нижчою:

- для придбаних товарів - ціни придбання;

- для самостійно виготовлених товарів - звичайних цін;

- для необоротних активів - бухгалтерської балансової (залишкової) вартості на початок періоду операції.

Щодо експорту послуг, то тут також $є$ свої особливості. Згідно 3 п. 185.1 ПКУ, об'єктом оподаткування ПДВ $є$ операції платників податку 3 постачання послуг, місце постачання яких розташоване на митній території України, а також постачання послуг з міжнародних перевезень пасажирів і багажу та вантажів залізничним, автомобільним, морським і річковим та авіаційним транспортом [20]. Тож у разі постачання послуг, місце постачання яких розташоване за межами митної території України, вартість таких послуг не є об'єктом оподаткування ПДВ. Для визначення чи є операція з постачання послуг нерезиденту об’єктом оподаткування ПДВ, необхідно скористатися ПКУ, а також можна використати наведений алгоритм (рис. 1).

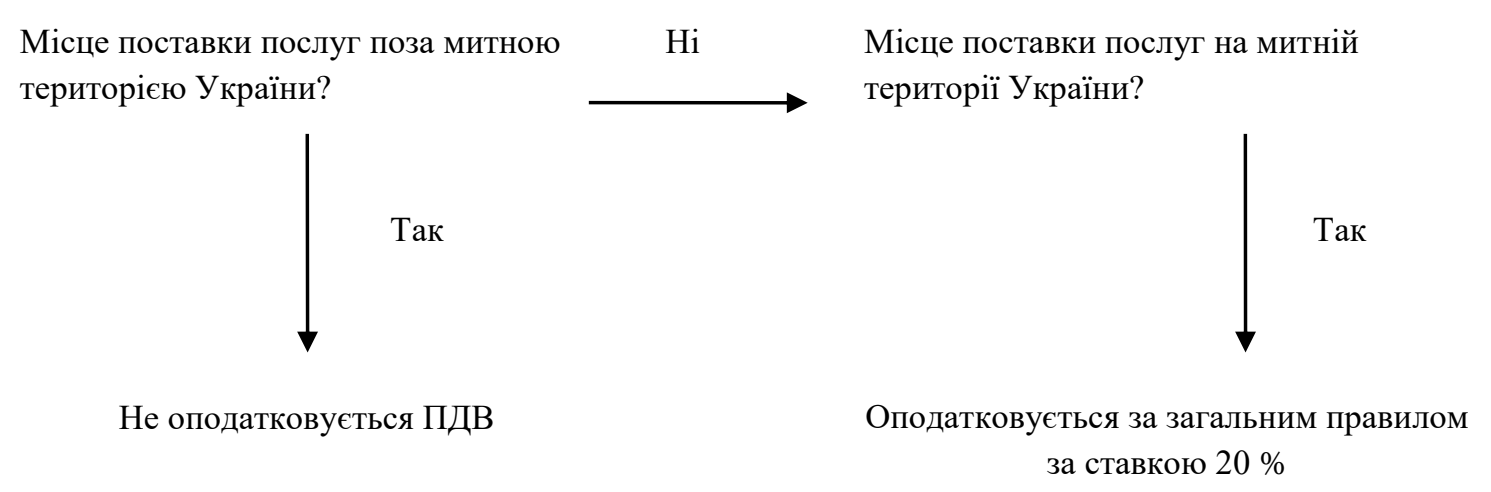

Рис. 1. Алгоритм визначення ставки ПДВ при постачанні послуг нерезиденту

Питання визначення місця постачання послуг регулюється ст. 186 Податкового кодексу України. Так місцем постачання послуг, зазначених у п. 186.2 ПКУ, буде місце їх фактичного надання, крім послуг, пов'язаних із нерухомим майном, місцем надання яких вважається фактичне місцезнаходження такого майна. А місцем постачання послуг, зазначених у п. 186.3 ПКУ, буде місце, в якому отримувач послуг зареєстрований як суб'єкт господарювання, або - у разі відсутності такого місця - місце постійного чи переважного його проживання (крім надання в оренду (лізинг) транспортних засобів та банківських сейфів). У всіх інших випадках місцем постачання послуг буде місце реєстрації постачальника послуг згідно з п. 186.4 ПКУ [20]. 
Послуги, місцем постачання яких є митна територія України, оподатковуються за ставкою ПДВ 20 \%. Якщо ж місце постачання послуг поза митною територією України, то така операція не оподатковується.

Дату виникнення зобов'язань при постачанні послуг визначають за правилом першої події: або за датою зарахування коштів від замовника, або за датою виконання послуги.

Базою оподаткування є договірна (контрактна) вартість, але не нижче за звичайні ціни [20]. Якщо база оподаткування виражена в іноземній валюті, то слід брати валютний курс Національного банку України на дату виникнення податкових зобов'язань з ПДВ.

В цілому спільні та відмінні риси оподаткування ПДВ експорту товарів та послуг можна згрупувати за певними показниками (табл. 1).

Спільні та відмінні риси оподаткування ПДВ експортних операцій

Таблиияя 1

\begin{tabular}{|c|c|c|c|}
\hline $\begin{array}{l}\text { № } \\
\text { 3/ח }\end{array}$ & Показники & Експорт товарів & Експорт послуг \\
\hline 1 & Чи є об’єктом оподаткування ПДВ & Так & Так, але $\epsilon$ виключення \\
\hline 2 & Ставка податку, що застосовується & $0 \%$ & $\begin{array}{c}20 \%, \text { або не } \\
\text { оподатковується }\end{array}$ \\
\hline 3 & $\begin{array}{c}\text { Дата виникнення податкових } \\
\text { зобов'язань }\end{array}$ & $\begin{array}{c}\text { Дата оформлення митної } \\
\text { декларації }\end{array}$ & За правилом першої події \\
\hline 4 & База оподаткування & $\begin{array}{c}\text { Договірна (контрактна) } \\
\text { вартість, але не нижча за } \\
\text { звичайні ціни }\end{array}$ & $\begin{array}{c}\text { Договірна (контрактна) } \\
\text { вартість, але не нижче за } \\
\text { звичайні ціни }\end{array}$ \\
\hline 5 & Документальне оформлення & Податкова накладна & $\begin{array}{c}\text { Податкова накладна на } \\
\text { операції, що } \\
\text { оподатковуються }\end{array}$ \\
\hline 6 & $\begin{array}{c}\text { Необхідність визначення місця } \\
\text { постачання для цілей оподаткування }\end{array}$ & Не потрібно & Потрібно \\
\hline
\end{tabular}

Як бачимо, відмінності виникають через таку особливість послуг, як невидимий перетин кордону. Тому різниця викликає необхідність визначення місця постачання послуг від якого і залежить, чи буде оподатковуватися така операція, чи ні, а також є відмінності в даті виникнення податкових зобов'язань та ставці податку, що застосовується. До спільного можна зарахувати те, що однаковою $є$ база оподаткування та документальне оформлення нарахованого податку податковою накладною.

Висновок. У результаті проведеного дослідження було вирізнено спільні та відмінні риси обліку й оподаткування експортних операцій. Встановлено, що спільним є переважно відображення операцій на рахунках бухгалтерського обліку способом подвійного запису. Проте відображення цих операцій відбувається на підставі різних первинних документів. Основною відмінністю таких операцій $\epsilon$ ї оподаткування. По-перше, необхідно чітко розмежовувати експорт товарів та експорт послуг, оскільки від цього залежить нарахування податку на додану вартість. По-друге, при експорті послуг потрібно чітко визначати, які послуги надаються поза митною територією України, а які на митній території України для того, щоб визначити, чи є така операція об'єктом оподаткування ПДВ. По-третє, необхідно достовірно визначити дату виникнення податкових зобов'язань, оскільки для експорту товарів та експорту послуг вони є різними. По-четверте, визначення ставки податку. Зазвичай всі знають, що при експорті ПДВ 0 \%. Однак є одне «але». При експорті послуг ставка ПДВ може становити 20 \%, або взагалі операція не оподатковується, а при експорті товарів, щоб застосовувати цю ставку, необхідно мати документальне підтвердження того, що така операція є дійсно експортною, а також уряд визначає певні категорії товарів, щодо яких не застосовується ставка ПДВ 0 \% при експорті. Тому якщо ваш товар $\epsilon$ зазначений у переліку товарів, що не оподатковуються за ставкою 0 \%, то необхідно враховувати це $\mathrm{i}$ при нарахуванні ПДВ, і при відображенні в обліку. По-п’яте, документальне оформлення нарахованого податку. При експорті товарів виписується податкова накладна 3 певними особливостями і не видається покупцю, а залишається у продавця. При експорті послуг податкова накладна складається лише на операції з місцем постачання на території України та за загальними правилами.

В цілому облік зовнішньоекономічних операцій завжди відрізнявся як особливостями, так i складнощами, порівняно з операціями в межах України. Тому специфіка даних операцій вплинула і на податковий облік. Однак знання бухгалтером необхідних нормативних актів та інструкцій дозволить йому без помилок відображати дані операції в бухгалтерському обліку та звітності.

\section{Список використаної літератури:}

1. Бухгалтерський облік 15 «Дохід» : положення (стандарт) від 29.11.1999 р., № 290 / Міністерство фінансів України [Електронний ресурс]. - Режим доступу : https://zakon.rada.gov.ua/laws/show/z0860-99. 
2. Бухгалтерський облік 21 «Вплив змін валютних курсів»: міжнародний стандарт: від 01.01.2012 р. [Електронний ресурс]. - Режим доступу : https://zakon.rada.gov.ua/laws/show/929_022.

3. Бухгалтерський облік 21 «Вплив змін валютних курсів» : положення (стандарт) від 10.08.2000 р., № 193 / Міністерство фінансів України [Електронний ресурс] - Режим доступу : https://zakon1.rada.gov.ua/laws/show/z0515-00.

4. Волотковська Ю. Експорт товарів: заповнюємо податкову накладну / Ю.Волотковська // Бібліотека «Баланс». - 2016. - № 7. - С. 27-30.

5. Гордополов В.Ю. Методологічні положення бухгалтерського обліку експортно-імпортних операцій підприємств / В.Ю. Гордополов // Агросвіт. - 2018. - № 13. - С. 15-27.

6. Гордополов В.Ю. Складові зовнішньоекономічної діяльності як об'єкта управління / В.Ю. Гордополов // Вісник ЖДТУ / Серія : Економічні науки. - 2016. - № 4 (78). - С. 43-60.

7. Давидова К. Експорт та імпорт товарів / К.Давидова // // Бібліотека «Баланс». - 2018. - № 13. - С. 170-178.

8. Єфімчук O. Експорт товарів із відстроченням платежу / О.Сфімчук // Все про бухгалтерський облік. 2015. - № 106 (Спецвипуск). - С. 29-31.

9. Єфімчук O. Експорт товарів на умовах повної або часткової передоплати / O.Сфімчук // Все про бухгалтерський облік. - 2015. - № 106 (Спецвипуск). - С. 25-28.

10. Жиглей I.B. Бухгалтерський облік експортно-імпортних операцій за контрактами, що містять валютноцінові застереження: методичний аспект / I.B. Жиглей // Науковий вісник Буковинського державного фінансово-економічного університету / Економічні науки : збірник наукових праць. - Чернівці : БДФЕУ, 2014. - Вип. 26. - С. 338-344.

11. Жиглей І.В. Методичне забезпечення бухгалтерського обліку експортних операцій за контрактами, що містять валютно-цінові застереження / І.В. Жиглей // Вектори розвитку фінансового потенціалу суб'єктів господарювання : Матеріали міжнародної науково-практичної конференції (1-5 лютого 2014 р.) ; відповідальний редактор В.В. Глущенко. - Х. : ХНУ ім. Каразіна, 2014. - 296 с.

12. Кантерман О. Експорт товарів: які документи потрібно оформити / О.Кантерман. // Бібліотека «Баланс». 2016. - № 16. - C. 9-11.

13. Карпенко Н.Г. Особливості обліку експорту товарів / Н.Г. Карпенко // Бухгалтерський облік, аналіз та аудит ; Мукачівський державний університет. - 2017. - № 9. - С. 1134-1138.

14. Коваленко O. Експорт товарів: чи очікувати перетину кордону для застосування нульової ставки? / О.Коваленко // Все про бухгалтерський облік. - 2016. - № 20. - С. 36.

15. Ксендзук В.В. Методи управління валютними ризиками в зовнішній торгівлі / В.В. Ксендзук // Вісник ЖДТУ / Серія : Економічні науки. - 2016. -№ 1 (75). - С. 142-150.

16. Митний кодекс України від 13.03.2013 р., № 4495-VI [Електронний ресурс]. - Режим доступу : http://sfs.gov.ua/mk/.

17. Михайлова T. Експорт товарів: коли визнавати дохід в обліку? / Т.Михайлова // Все про бухгалтерський облік. - 2015. - № 61. - С. 4-5.

18. Міжнародний маркетинг https://pidruchniki.com/1494080752342/marketing/yaki_osoblivosti_eksportu_formi_vihodu_mizhnarodniy_rinok.

19. Оляднічук Н.В. Облік експортно-імпортних операцій / Н.В. Оляднічук, О.Д. Підлубна // Облік і фінанси. 2017. - № 1 (75). - С. 48-56.

20. Податковий кодекс України від 02.12.2010 р., № 2755-VI [Електронний ресурс]. - Режим доступу : http://sfs.gov.ua/nk/.

21. Порядок заповнення податкової накладної : наказ від 31.12.2015 р., № 1307 / Міністерство фінансів України [Електронний ресурс]. - Режим доступу : https://zakon.rada.gov.ua/laws/show/z0137-16.

22. Про валюту і валютні операції : Закон України від 21.26.2018 р., №2473 / Міністерство фінансів України [Електронний ресурс]. - Режим доступу : https://zakon.rada.gov.ua/laws/show/2473-19.

23. Про зовнішньоекономічну діяльність : Закон України від 16.04.1991 р., № 960 / Верховна Рада України [Електронний ресурс]. - Режим доступу : https://zakon.rada.gov.ua/laws/show/959-12.

24. Рижикова О. Експорт товарів: коли виникають податкові зобов'язання із ПДВ? / О.Рижикова // Все про бухгалтерський облік. - 2015. - № 48. - С. 30-32.

25. Сайт Державної служби статистики [Електронний ресурс]. - Режим доступу : http://www.ukrstat.gov.ua.

26. Сисюк С.В. Оцінка та страхування ризиків у зовнішньоекономічній діяльності: обліковий аспект / С.В. Сисюк // Вісник ЖДТУ / Серія : Економічні науки. - 2015. - № 2 (72). - С. 86-90.

27. Форостина М. Коли нараховувати ПДВ при експорті товарів / М.Форостина // Все про бухгалтерський облік. - 2018. - № 86. - С. 22.

28. Целуйко О. Експорт товарів і поставка послуг нерезидентам: облік доходів і витрат / О.Целуйко // Бібліотека «Баланс». - 2015. - № 22. - С. 76-79.

29. Юлін А. Експорт товарів: на яку дату визнавати дохід / А.Юлін // Все про бухгалтерський облік. - 2017. № 78. - C. 6-7.

\section{References:}

1. Ministerstvo finansiv Ukrainy (1999), Buhgalters'kyj oblik 15 «Dokhid», polozhennia (standart) vid 29.11 .1999 r., No. 290, [Online], available at: https://zakon.rada.gov.ua/laws/show/z0860-99

2. Ministerstvo finansiv Ukrainy (2012), Buhgalters'kyj oblik 21 «Vplyv zmin valjutnykh kursiv», mizhnarodnyj standart vid 01.01.2012 r., [Online], available at: https://zakon.rada.gov.ua/laws/show/929_022 
3. Ministerstvo finansiv Ukrainy (2000), Buhgalters'kyj oblik 21 «Vplyv zmin valjutnykh kursiv», polozhennia (standart) vid 10.08.2000 r., No. 193, [Online], available at: https://zakon1.rada.gov.ua/laws/show/z0515-00

4. Volotkovs'ka, Ju. (2016), «Eksport tovariv: zapovnjujemo podatkovu nakladnu», Biblioteka «Balans», No. 7, pp. 27-30

5. Gordopolov, V.Ju. (2018), «Metodologichni polozhennja buhgalters'kogo obliku eksportno-importnyh operacij pidpryjemstv», Agrosvit, No. 13, pp. 15-27.

6. Gordopolov, V.Ju. (2016), «Skladovi zovnishn'oekonomichnoi' dijal'nosti jak ob'jekta upravlinnja», Visnyk ZhDTU, Serija Ekonomichni nauky, No. 4 (78), pp. 43-60.

7. Davydova, K. (2018), «Eksport ta import tovariv», Biblioteka «Balans», No. 13, pp. 170-178.

8. Jefimchuk, O. (2015), «Eksport tovariv iz vidstrochennjam platezhu», Vse pro buhgalters'kyj oblik, No. 106 (Specvypusk), pp. 29-31.

9. Jefimchuk, O. (2015), «Eksport tovariv na umovah povnoi' abo chastkovoi' peredoplaty», Vse pro buhgalters'kyj oblik, No. 106 (Specvypusk), pp. 25-28.

10. Zhyglej, I.V. (2014), «Buhgalters'kyj oblik eksportno-importnyh operacij za kontraktamy, shho mistjat' valjutno-cinovi zasterezhennja: metodychnyj aspect», Naukovyj visnyk Bukovyns'kogo derzhavnogo finansovo-ekonomichnogo universytetu, Ekonomichni nauky, zbirnyk naukovyh prac', BDFEU, Chernivci, Issue 26, pp. 338-344.

11. Zhyglej, I.V. (2014), «Metodychne zabezpechennja buhgalters'kogo obliku eksportnyh operacij za kontraktamy, shho mistjat' valjutno-cinovi zasterezhennja», Vektory rozvytku finansovogo potencialu sub'jektiv gospodarjuvannja, materialy mizhnarodnoi' naukovo-praktychnoi' konferencii' (1-5 ljutogo 2014 r.), vidpovidal'nyj redaktor Glushhenko, V.V., HNU im. Karazina, H., 296 p.

12. Kanterman, O. (2016), «Eksport tovariv: jaki dokumenty potribno oformyty», Biblioteka «Balans», No. 16, pp. 9-11.

13. Karpenko, N.G. (2017), «Osoblyvosti obliku eksportu tovariv», Buhgalters'kyj oblik, analiz ta audit, Mukachivs'kyj derzhavnyj universytet, No. 9, pp. 1134-1138.

14. Kovalenko, O. (2016), «Eksport tovariv: chy ochikuvaty peretynu kordonu dlja zastosuvannja nul'ovoi' stavky?», Vse pro buhgalters'kyj oblik, No. 20, P. 36.

15. Ksendzuk, V.V. (2016), «Metody upravlinnja valjutnymy ryzykamy v zovnishnij torgivli», Visnyk ZhDTU, Serija Ekonomichni nauky, No. 1 (75), pp. 142-150.

16. Verhovna Rada Ukrai'ny (2013), Mytnyj kodeks Ukrai'ny vid 13.03.2013 r., No. 4495-VI, [Online], available at: http://sfs.gov.ua/mk/

17. Myhajlova, T. (2015), «Eksport tovariv: koly vyznavaty dohid v obliku?», Vse pro buhgalters'kyj oblik, No. 61, pp. 4-5.

18. Mizhnarodnyj marketing, [Online], available at: https://pidruchniki.com/1494080752342/marketing/yaki_osoblivosti_eksportu_formi_vihodu_mizhnarodniy_rinok

19. Oljadnichuk, N.V. and Pidlubna, O.D. (2017), «Oblik eksportno-importnyh operacij», Oblik i finansy, No. 1 (75), pp. $48-56$.

20. Verhovna Rada Ukrai'ny (2010), Podatkovyj kodeks Ukrai'ny vid 02.12.2010 r., No. 2755-VI, [Online], available at: http://sfs.gov.ua/nk/

21. Ministerstvo finansiv Ukrai'ny (2015), Porjadok zapovnennja podatkovoi' nakladnoi', nakaz vid 31.12.2015 r., No. 1307, [Online], available at: https://zakon.rada.gov.ua/laws/show/z0137-16

22. Ministerstvo finansiv Ukrai'ny (2018), Pro valjutu i valjutni operacii', Zakon Ukrai'ny vid 21.26.2018 r., No. 2473, [Online], available at: https://zakon.rada.gov.ua/laws/show/2473-19

23. Verhovna Rada Ukrai'ny (1991), Pro zovnishn'oekonomichnu dijal'nist', Zakon Ukrai'ny vid 16.04.1991 r., No. 960, [Online], available at: https://zakon.rada.gov.ua/laws/show/959-12

24. Ryzhykova, O. (2015), «Eksport tovariv: koly vynykajut' podatkovi zobov'jazannja iz PDV?», Vse pro buhgalters'kyj oblik, No. 48, pp. 30-32.

25. Sajt Derzhavnoi' sluzhby statystyky, [Online], available at: http://www.ukrstat.gov.ua

26. Sysjuk, S.V. (2015), «Ocinka ta strahuvannja ryzykiv u zovnishn'oekonomichnij dijal'nosti: oblikovyj aspect», Visnyk ZhDTU, Serija Ekonomichni nauky, No. 2 (72), pp. 86-90.

27. Forostyna, M. (2018), «Koly narahovuvaty PDV pry eksporti tovariv», Vse pro buhgalters'kyj oblik, No. 86, P. 22.

28. Celujko, O. (2015), «Eksport tovariv i postavka poslug nerezydentam: oblik dohodiv i vytrat», Biblioteka «Balans», No. 22, pp. 76-79.

29. Julin, A. (2017), «Eksport tovariv: na jaku datu vyznavaty dohid», Vse pro buhgalters'kyj oblik, No. 78, pp. 6-7.

Жиглей Ірина Вікторівна - доктор економічних наук, професор, професор кафедри обліку і аудиту Державного університету «Житомирська політехніка».

Наукові інтереси:

- бухгалтерський облік соціально відповідальної діяльності суб'єктів господарювання;

- розвиток теорії і методології бухгалтерського обліку в умовах гібридної війни;

- облік зовнішньоекономічної діяльності суб'єктів господарювання.

Осіпчук Дарина Сергіївна - магістрант Державного університету «Житомирська політехніка». Наукові інтереси:

- бухгалтерський облік та аналіз зовнішньоекономічної діяльності. 